\title{
O PROCESSO DE CONSTRUÇÃO DO NOVO MARCO LEGAL MIGRATÓRIO NO BRASIL: ENTRE A IDEOLOGIA DA SEGURANÇA NACIONAL E O DIREITO HUMANO DE MIGRAR
}

\author{
BUILDING THE NEW LEGAL FRAMEWORK FOR MIGRATION IN BRAZIL: \\ BETWEEN THE NATIONAL SECURITY IDEOLOGY AND THE HUMAN RIGHT TO \\ MIGRATE
}

\begin{abstract}
Laura Madrid Sartaretto
Doutora em Direito na Universidade Federal do Rio Grande do Sul, Mestre em Direito pela Universidade Federal do Rio Grande do Sul e Mestre em Direito Internacional Público pela University College London - UCL. Possui graduação em Ciências Jurídicas e Sociais pela Universidade Federal do Rio Grande do Sul (2009).
\end{abstract}

Roberta Camineiro Baggio

Doutora em Direito pela Universidade Federal de Santa Catarina (2008), mestre em Direito pela Universidade do Vale do Rio dos Sinos (2001) e graduada em Direito pela Universidade Federal de Uberlândia (1999) Atua nas áreas de Direitos Humanos e Constitucionalismo na América Latina.

\begin{abstract}
Resumo
No Brasil, desde os anos 80 , se mantiveram vestígios de legislações autoritárias, como é o caso do Estatuto de Estrangeiro, que tinha fundamento no paradigma da segurança nacional e da proteção do mercado de trabalho interno e que, mesmo tendo se tornado anacrônico com a aprovação da Constituição de 1988, produziu efeitos no ordenamento jurídico por 37 anos. Em 2017, finalmente, o referido Estatuto foi revogado pela aprovação da nova Lei de Migração. Apesar da história que precedeu a aprovação do novo marco regulatório, marcada pela construção democrática de propostas feitas pela $1^{\text {a }}$ COMIGRAR (Conferência Nacional sobre Migrações e Refúgio) e consolidadas por uma comissão de especialistas, constituída em 2013, as alterações sofridas ao longo do processo de tramitação na Câmara de Deputados, deixaram o texto final muito similar a um projeto de lei mais antigo, afastando-se consideravelmente da proposta de promoção e proteção dos direitos humanos dos migrantes produzida pela referida comissão. Ademais, as negociações que envolveram o processo de votação; os vetos realizados pelo poder executivo (aprovados pelo Congresso Nacional) e, ainda, o decreto regulamentador expedido pela presidência da república; fizeram com que a nova Lei ficasse muito aquém das expectativas da sociedade
\end{abstract}


civil envolvida com o tema. Esse artigo se propõe a fazer uma reconstrução histórica do processo de consolidação do novo marco legal problematizando os motivos pelos quais o texto aprovado pelo Congresso Nacional não obteve sucesso em suprimir as marcas ideológicas da segurança nacional alçando o Brasil a uma concepção de migração como um direito humano fundamental.

Palavras-chave: Lei de Migração. Direito Humano a Migrar. Segurança Nacional. Processo Legislativo.

\begin{abstract}
In Brazil, since the 1980s, there have been traces of authoritarianism in the legislation, such as in the Foreigners Statute, which was based on the paradigm of national security and the protection of the internal labor market. Although it became anachronistic with the promulgation of the 1988 Constitution, it continued to be effective in the legal system for 37 years. Finally, in 2017, that law was revoked by the passing of the new Law of Migration. Despite the history that preceded the approval of the new regulatory framework, marked by the democratic construction of proposals made by the 1st National Conference on Migrations and Refuge (COMIGRAR) and consolidated by a Committee of Experts, established in 2013, the changes imposed during the legislative process in the House of Representatives left the final instrument very similar to the older bill, moving away from the proposal of promoting and protecting human rights of migrants produced by the Committee. In addition, the negotiations that involved the voting process; the vetoes imposed by the Executive Branch (approved by the National Congress), as well as the regulatory decree issued by the Presidency of the Republic; made the new Law far away from the expectations of the civil society involved in the process. This article proposes to develop a historical review of the consolidation process of the new legal framework, addressing the reasons why the instrument approved by the National Congress did not succeeded in suppressing the of national security ideological features, failing in elevating Brazil to a conception of migration as a fundamental human right.
\end{abstract}

Keywords: Migration Law. Human Right to Migrate. National Security. Legislative process.

\title{
CONSIDERAÇÕES INICIAIS
}

Em 2017 foi aprovada no Brasil a Lei 13.445 que passou a regulamentar as questões de migração em substituição ao Estatuto do Estrangeiro, Lei 6.815 de 1980. $A$ priori, essa mudança legislativa deveria representar um avanço para a ordem constitucional tanto pelo processo de mobilização social que impulsionou um debate amplo sobre os desafios a serem contemplados pela nova legislação como em termos de superação de uma herança legal autoritária, uma vez que a Lei 6.815 - elaborada 
ainda no final do regime militar - foi fortemente pautada pela lógica da segurança nacional.

Contudo, o modo como se consolidou o processo legislativo e, sobretudo, a fundamentação dos vetos presidenciais também presente no decreto de regulamentação da nova lei, reafirmaram a lógica da segurança nacional, deslindando as dificuldades de superação de nossa cultura autoritária e dificultando a consolidação da tão reivindicada condição da migração como um direito humano fundamental.

Reconhecendo os avanços que ocorreram com a chegada do novo marco legal, mas problematizando seus limites de construção histórica e suas dificuldades em se colocar como uma legislação de superação da dinâmica estatal anteriormente predominante, o artigo apresentará, primeiramente, as marcas da ideologia da segurança nacional consolidadas pelo Estatuto Estrangeiro e suas condições de permanência na ordem constitucional de 1988, mesmo diante de sua flagrante incompatibilidade; para depois fazer a reconstrução histórica do processo de mobilização social que, com apoio institucional, contribuiu para a alteração do marco legal. Por fim, será feita uma análise dos vetos presidenciais, aceitos pelo Congresso Nacional, demonstrando a persistência em se tratar o tema migratório desde a lógica da segurança nacional.

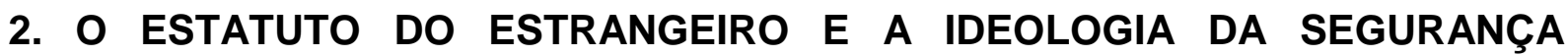 NACIONAL}

Muito se falou, na última década, sobre a necessidade de revogação do Estatuto do Estrangeiro, Lei n. 6.815/80, que regulava o tratamento de imigrantes no Brasil. Instrumento jurídico elaborado e adotado no ocaso do regime autoritário, que se iniciou em meados da década de 60, o Estatuto do Estrangeiro submetia a entrada e permanência do estrangeiro no Brasil ao interesse nacional e, explicitamente estabelecia, em seu art. $2^{\circ}$, que a lei deveria atender precipuamente à segurança nacional, à organização institucional, aos interesses políticos, socioeconômicos e culturais do Brasil, bem assim à defesa do trabalhador nacional, deixando sem qualquer consideração a possibilidade de tratamento do tema desde o reconhecimento de direitos dos imigrantes.

Ainda que o Estatuto do Estrangeiro não tenha inaugurado a prática estatal de perseguição aos migrantes, já que esse tipo de atuação repressora pode ser constatada 
desde as políticas nacionalistas aplicadas pelo Estado Novo, que já colocavam o "imigrante na posição de indesejável, dificultando sua regularização migratória" (MORAES, 2016, p. 18), o que chama a atenção na exposição de motivos apresentada pelo então presidente da república, João Figueiredo, na mensagem ㄲo 64 , enviada ao Congresso Nacional para a apresentação do projeto de lei $n^{0} 09$, que viria a transformarse no famigerado Estatuto do Estrangeiro, é a sua filiação a uma clara ideologia de segurança nacional que precisa ser melhor compreendida.

Em um dos principais estudos de sistematização do fenômeno da ideologia da segurança nacional, nascida e consolidada sob a égide das ditaduras militarizadas na América-Latina, Joseph Comblin discorre sobre uma característica capaz de explicar os níveis de enraizamento dessa concepção no tecido social, o que nos ajuda a entender as condições da aprovação da Lei na década de 1980, a sua permanência no ordenamento jurídico constitucional depois de 1988 e as dificuldades de superação das práticas institucionais que ainda resistem à consideração de que as pessoas em situação de migração são portadoras de direitos. O êxito de tal característica é identificado por Comblin pela simplicidade exposta no conceito de segurança nacional, que adota uma operacionalidade totalizante da sociedade apenas pela definição de um inimigo. (COMBLIN, 1978, p. 55).

Esse tipo de operacionalidade já havia sido muito bem empregada nas experiências totalitárias europeias que desembocaram na $2^{\mathrm{a}}$ Grande Guerra mundial, com um alto grau de sucesso em relação à conquista dos corações e mentes daqueles que se identificavam como os "amigos da nação" e que, portanto, fariam parte de uma importante engrenagem de busca de um inesgotável patamar de segurança na luta contra um "inimigo". Isso pode ser explicado pela própria constituição atávica do ser humano, afinal, toda a sobrevivência da espécie vincula-se em última instância à busca por segurança. Ainda que Comblin tenha alertado para o fato de que existe um paradoxo de irracionalidade nessa lógica de busca da segurança, no sentido de que "a segurança absoluta tem um preço, que é a insegurança absoluta dos outros" (COMBLIN, 1978, p. 57); em sociedades individualizadas como as nossas, é complexo perceber tal armadilha, o que facilita não só a escolha do inimigo como a sua reificação ${ }^{1}$. Não foi difícil identificar, em meio à conjuntura mundial da guerra fria, que

\footnotetext{
${ }^{1} \mathrm{~A}$ ideia de reificação aqui adotada é aquela desenvolvida por Axel Honneth a partir de uma perspectiva própria à teoria do reconhecimento. A reificação seria uma consequência da recusa do ato de reconhecer o outro, uma rejeição social possibilitada pela própria desconsideração da condição de humanidade dos sujeitos. O reconhecimento, na concepção honnethiana, é a forma original de se relacionar com o mundo,
} 
os inimigos das "nações" militarizadas na América Latina seriam os comunistas, ainda que no caso brasileiro, essa ideologia política jamais tenha chegado perto de disputar o poder em condições reais de competição.

Identificado o inimigo e construída sua imagem ampla e abstrata de ameaça à segurança nacional, abre-se o caminho para um processo de despersonificação de todos aqueles que serão literalmente "enquadrados" no conceito de inimigo e, como já não são pessoas, também não necessitam mais de reconhecimento como seres portadores de direitos. Em se tratando de uma estratégia que investe na construção de um sentimento atávico sobre a segurança nacional, a despersonificação se torna difícil de ser notada e contribui para o alto grau de sucesso dessa doutrina na desconstrução do que Comblin classificou como algumas diferenciações que até então "pareciam fazer parte da herança da civilização" (COMBLIN, 1978, p. 55). Seriam elas: (a) a diferença entre violência e não-violência, já que os meios de combate aos inimigos que não mais compõe a lista dos portadores de direitos não importa. Numa perspectiva atávica "quem busca a segurança não questiona os meios" (COMBLIN, 1979, p. 56); (b) a diferença entre política externa e política interna, afinal, dentro da perspectiva de abstração do inimigo ele está "ao mesmo tempo dentro e fora do país; o problema, portanto, é o mesmo. Dependendo das circunstâncias, os mesmos meios podem ser empregados tanto para inimigos externos quanto para os internos." (COMBLIN, 1978, p. 56) e (c) a diferença entre violência preventiva e violência repressiva, pois a lógica de defesa da segurança nacional adota o combate a ameaças futuras que, além de mapeadas e identificadas, precisam ser "eliminadas" para que não se tornem "reais", por isso não há barreiras à declaração de uma guerra de prevenção contra os inimigos da nação (COMBLIN, 1978, p. 56).

Explicitadas as principais características e conjuntos conceituais que identificam as estratégias adotadas pela atuação militar na América Latina, torna-se simples se dar conta do quanto um tema como o das migrações fez parte da pauta prioritária desses governos. É curioso perceber que no apagar das luzes do regime ditatorial, proposto por um presidente favorável à abertura política - como era o caso de João Figueiredo - o Estatuto do Estrangeiro representasse uma estratégia explícita de

por isso, quando as pessoas tentam interagir umas com as outras, estão tentando ser compreendidas, dentro de suas especificidades, por seus companheiros de interação. A reificação ou a amnésia do reconhecimento é a perda da capacidade de entender as manifestações ou condutas dos sujeitos como tentativas de estabelecer relações de interação (HONNETH, 2007). 
sobrevivência. A segurança nacional precisaria continuar sendo defendida pela classe militar mesmo que estivesse fora do comando governamental e, para tanto, a manutenção da áurea fantasiosa e abstrata das ameaças futuras por parte dos estranhos que "vinham de fora" como modo de tornar constante a "guerra preventiva" era essencial.

$\mathrm{Na}$ fundamentação do projeto de lei é possível encontrar todas as características desenvolvidas até aqui. Podemos iniciar pela própria identificação do migrante como um estrangeiro, como já dito, o estranho que vem de fora e que sempre pode representar uma ameaça ao futuro da nação e, por isso, logo no primeiro ponto da fundamentação está explicitado que a lei proposta estaria "orientada no sentido de reduzir o afluxo de estrangeiros aos estritamente úteis e necessários ao nosso desenvolvimento, por não mais consultar aos interesses nacionais da imigração indiscriminada para o Brasil” (DCN, 27/05/1980, p. 1129).

Essas concepções de "utilidade" e desenvolvimento estavam vinculadas a uma ideia de proteção do mercado interno de trabalho, o que representou uma boa estratégia no sentido de demonstrar uma preocupação concreta do governo no processo de "defesa" de seus cidadãos, alimentando um imaginário social presente até hoje de que os migrantes são sempre uma ameaça na competição do mercado de trabalho. Por isso, a segunda fundamentação estabelecida foi a de que a nova lei daria "cumprimento às diretrizes governamentais no sentido de só permitir a radicação no, País, dos estrangeiros que venham complementar a mão-de-obra nacional, nos níveis de qualificação em que esta não puder atender à demanda resultante do atual processo de desenvolvimento econômico" (DCN, 27/05/1980, p. 1129).

A terceira justificativa pautou-se pela defesa de criação do Conselho Nacional de Imigração (CNIg), que com grandes poderes discricionários ao lado do poder executivo, passaria a ter condições de combater esse estrangeiro (chamado de alienígena!), sem qualquer consideração por supostos direitos, inclusive os vinculados aos laços familiares, afirmando a condição abstrata e despersonificada do migrante, bem como abarcando a indiferenciação do modo de coerção (violenta ou não-violenta) a ser aplicada no momento decisório de resolução das situações "ilegais. Vejamos o fundamento em sua literalidade:

O texto que ora submetemos a Vossa Excelência cria o Conselho Nacional de Imigração, permite a localização do alienígena em área determinada no País, possibilita a expulsão do estrangeiro, ainda que seja cônjuge ou pai de nacional brasileiro e faculta, em caráter excepcional e transitório, ao Poder Executivo 
solucionar a situação ilegal de estrangeiros no território brasileiro, mediante acordos bilaterais com os Governos interessados (DCN, 27/05/1980, p. 1129).

Hoje, já notórias as relações estabelecidas entre os governos latino-americanos e os EUA por meio da operação condor, tornam-se mais claros os objetivos dessa cooperação entre os países para o controle dos fluxos migratórios, constituindo-se como uma estratégia poderosa para o contexto da época. A faculdade do poder executivo em exercer a tarefa de "excepcionalmente" solucionar as situações de ilegalidade migratória com os governos interessados foi complementada pelo penúltimo ponto de fundamentação do projeto de lei em que os termos condicionantes à identificação das nações "amigas" cumprem o desiderato de tornar indiferente o local de combate do inimigo, afinal, como já dito anteriormente, este está ao mesmo tempo dentro e fora do país:

\begin{abstract}
A permissibilidade de solucionar, em colaboração com os Governos dos países que são fontes de imigração clandestina, a situação irregular dos seus nacionais em território brasileiro fica, entretanto, condicionada à assunção, por aqueles Governos, do compromisso de: a) controlarem estritamente a emigração para o Brasil; b) arcarem com os custos do transporte oriundos da deportação de seus nacionais; e c) prestarem cooperação técnica e financeira para o assentamento dos seus nacionais, que venham a ser beneficiados. (DCN, 27/05/1980, p. 1129).
\end{abstract}

Por fim, a última observação da mensagem presidencial que fundamenta o projeto de lei faz um derradeiro registro sobre essa possibilidade de legalização excepcional com base nos acordos bilaterais entre as nações amigas: ela só seria cabível mediante a comprovação de interesses baseados na segurança da nação:

\footnotetext{
Cumpre registrar, ainda, que essa legalização excepcional jamais alcançará estrangeiros que não preencham os requisitos mínimos exigidos para a concessão de visto permanente, ou sejam inconvenientes aos interesses ou à segurança nacional. (DCN, 27/05/1980, p. 1129).
}

Em menos de três meses o país veria o projeto de lei no 09/80 ser aprovado e promulgado como o novo Estatuto do Estrangeiro (Lei 6.815/80), dando materialidade fidedigna aos preceitos da doutrina de segurança nacional e vindo a consolidar-se como um de seus mais eficazes instrumentos de atuação legal, exatamente no momento em que o Brasil voltaria a receber os seus exilados políticos, depois da aprovação da Lei 
de Anistia de 1979 e que as negociações para a abertura política do regime estavam em curso.

A grande questão que se coloca é: como explicar que um texto legal dessa natureza, construído em bases tão profundas da ideologia da segurança nacional tenha resistido à chegada de um novo e democrático texto constitucional e perdurado por mais quase 30 anos?

A transição política brasileira nos fornece alguns elementos importantes para a consideração dessa questão. Diferente de países como a Argentina em que o regime colapsou depois de sofrer um alto nível de desgaste em decorrência da crise econômica e da Guerra das Malvinas ficando sem qualquer condição de negociação de termos ou garantias de impunidade (NINO, 2006); no Brasil, vivenciamos uma transição dirigida pelo próprio comando do regime. Ainda que houvesse uma forte divergência interna entre os militares sobre a conveniência ou não na promoção da abertura do regime, o fato é que houve uma abertura conduzida sob o slogan "lenta, gradual e segura". Esse tipo de transição bloqueou um debate mais amplo sobre o significado da redemocratização e o enfrentamento das violações aos direitos humanos ocorridas ao longo do regime, beneficiando a permanência de uma cultura autoritária que comodamente seguiu inspirando práticas sociais e instâncias institucionais que jamais foram questionadas ou obrigadas a refletir sobre os fatos do passado, como é o caso das estruturas policiais que continuaram sendo militarizadas no Brasil. Nesse sentido, a Constituição de 1988 é um marco decisivo na repactuação social e democrática do Brasil, mas carrega o pesado fardo de conformar uma nova ordem jurídico-política que pretendia ser democrática com um considerável legado autoritário.

Esse caminho dificultou o alcance de importantes pilares normativos da chamada justiça de transição. Se, por um lado, a reparação - apenas em sua dimensão econômica - foi privilegiada como forma quase única de assunção por parte do Estado de medidas "corretivas" do passado, os demais pilares como direito à memória e verdade, a responsabilização dos agentes do Estado pelos crimes cometidos e as reformas institucionais ficaram secundarizadas no cenário da redemocratização do Brasil. Isso contribui para a compreensão das condições de permanência de um conjunto de legislações produzidas no período autoritário, que sem qualquer ameaça de questionamento mesmo sendo inconstitucionais, seguiram produzindo decisões e conformando práticas bem longe das desejáveis em uma sociedade que se pretendia democrática, como é o caso do Estatuto do Estrangeiro. 
Não raras vezes, ao longo desses quase 30 anos de uma nova ordem constitucional, ouviu-se relatos de arbitrariedades pautadas em bases legais anacrônicas como a própria Lei de Segurança Nacional, para ficar no âmbito temático debatido nesse trabalho².

No atual contexto político brasileiro, um passado anamnético parece vir à tona cobrar o preço do silêncio. Desde que a Presidenta Dilma Rousseff foi deposta por um golpe institucional do poder legislativo, por meio de um processo político de impedimento, uma nova onda de autoritarismos tem assolado a democracia brasileira. Em meio a uma série de manifestações de intolerância e saudosismos em relação ao regime militar, por parte de alguns setores da sociedade brasileira, os poderes institucionais seguem mais à vontade do que nunca recolocando às claras o protagonismo da ideologia da segurança nacional em temas vinculados às questões migratórias, como ocorreu em 7 de abril de 2016, quando uma professora universitária italiana, residente no Brasil, foi convocada a prestar esclarecimentos na superintendência da polícia federal para a instrução de inquérito policial, com base nos inconstitucionais arts. 106 e 107 do Estatuto do Estrangeiro, por "estar militando em sindicatos e partidos políticos no território nacional".

O inquérito foi arquivado pela Justiça Federal de Belo Horizonte. O juiz federal, considerando atípicas as condutas imputadas à professora, "vez que os artigos mencionados na Lei $6.815 / 80$, como se demonstrou, não foram recepcionados pela CF/88", justificou ser "evidente a ausência de justa causa para a continuidade das investigações e possível instauração de ação penal" (UNIVERSIDADE FEDERAL DE MINAS GERAIS, 2016). Ainda assim, em 16 de abril, a Federação Nacional dos Policiais Federais (FENAPEF) emitiu nota à imprensa brasileira afirmando que, com base nos arts. 106 e 107 do Estatuto do Estrangeiro, que proibia a participação dos imigrantes em atividades de natureza política, promoveria a detenção e expulsão de estrangeiros que participassem de manifestações políticas relativas ao impeachment da Presidenta Dilma Rousseff (FENAPEF, 2016).

\footnotetext{
${ }^{2}$ No ano de 2008 o Ministério Público do Estado do Rio Grande do Sul, no procedimento administrativo n . 16315-0900/07-9, que serviu de base para uma série de ações civis públicas que visavam impedir a formação de acampamentos do Movimento dos Trabalhadores Rurais Sem Terra (MST), invoca a Lei de Segurança Nacional (7.170/83) para indicar os perigos e as inadequações das atividades desenvolvidas pelo movimento. $O$ conteúdo das Ações Civis Públicas estão disponíveis em: https://www.mprs.mp.br/noticias/14480/
} 
Outro exemplo recente foi o indeferimento por parte do atual ministro da justiça, Torquato Jardim, de requerimento de anistia política formulado por Jan Honore Talpe ${ }^{3}$ por ter sido perseguido durante a ditadura de 1964. No despacho de № 49 de 07 de fevereiro de 2018, o ministro fundamentou sua decisão no fato de que "o requerente não possui nacionalidade brasileira e que ainda havia à época da suposta perseguição sofrida vedação ao exercício de atividade política por estrangeiro" (DOU, 8/02/2018, p. 74) deixando assim de acolher a decisão da Comissão de Anistia, que havia deferido o pedido de Jan há mais de um ano, em 6 de dezembro de 2016. Esse último caso chama a atenção, sobretudo, porque já ocorreu sob a égide da nova Lei de Migração.

Diante desse quadro, a fundamentação dada pelo poder executivo aos vetos da nova Lei de Migração bem como a regulamentação dada à Lei pelo decreto 9.199/17 são apenas mais um conjunto de ações que reforçam a tese de que a lógica da segurança nacional continua tão presente quanto sempre esteve, ameaçando mais do que nunca processos democráticos importantes como o que antecedeu a aprovação do novo marco regulatório da migração no Brasil e que será objeto de apreciação no próximo tópico.

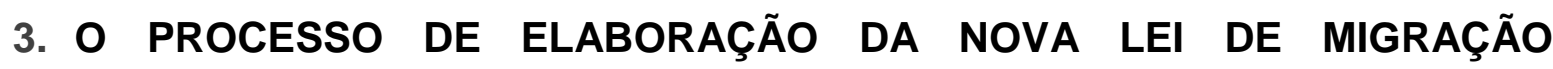 BRASILEIRA}

\subsection{O anteprojeto da nova Lei de Migração e a Comissão de Especialistas}

A promulgação da Constituição Federal de 1988 (CF/88) destinou à pessoa imigrante um tratamento igualitário aos brasileiros e às brasileiras. Conforme prevê o artigo $5^{\circ}$, caput da CF 88, "todos são iguais perante a lei, sem distinção de qualquer natureza, garantindo-se aos brasileiros e aos estrangeiros residentes no País a inviolabilidade do direito à vida, à liberdade, à igualdade, à segurança e à propriedade" (BRASIL, 1988).

O marco legal democrático inaugurado no Brasil, em 1988, por si só já exigiria revisão da legislação relativa ao tratamento do imigrante no país, sobretudo no que se refere à necessidade de adequação da proteção oferecida pela $\mathrm{CF} / 88$ aos direitos

\footnotetext{
${ }^{3} J a n$ Honoré Talpe, de nacionalidade belga, veio morar no Brasil em 1965 e tornou-se militante da Ação Popular (AP) durante a ditadura brasileira de 1964, tendo sido preso, demitido e expulso do país em 1969.
} 
fundamentais dos imigrantes, exigência do princípio da igualdade, que discrepava do tratamento discriminatório que o Estatuto do Estrangeiro dispensava aos mesmos.

Nos anos iniciais do século XXI, o Brasil passou por um período de desenvolvimento e crescimento econômico, o que fez com que não apenas brasileiros que haviam emigrado em décadas anteriores voltassem ao país, como fomentou um fluxo migratório recente de pessoas que vinham compor a força de trabalho exigida pelo crescimento econômico acelerado. Em razão da migração de retorno, de novos fluxos migratórios que foram se organizando em direção ao país e da falta de harmonização entre o Estatuto do Estrangeiro e a $\mathrm{CF} / 88$, foi necessária uma intensa produção de normas relativas às questões de migrações, sobretudo por meio de instrumentos infra legais - como as resoluções de órgãos colegiados - o que não significou uma necessária articulação do tema em termos de elaboração de uma nova política nacional sobre migrações, ao contrário, foi tornando a aplicação dessas normativas cada vez mais complexas. (CLARO, 2015, p. 121).

A temática já havia sido enfrentada parcialmente no ano de 1997, quando o Congresso Nacional aprovou norma regulatória do acesso e proteção aos refugiados no território nacional. A Lei n. 9.474/97, conhecida como Estatuto dos Refugiados (BRASIL, 1997), estabeleceu, do ponto de vista interno, a proteção destinada aos refugiados que, no plano internacional, é prevista na Convenção de 1951.

Nesse contexto de fluxos imigratórios em direção ao Brasil no século XXI, um dos marcos mais importantes foi representado pela recente imigração haitiana ${ }^{4}$. Desde meados de 2010 (ano em que o Haiti foi atingido por um terremoto que ocasionou a morte de 300 mil pessoas e o deslocamento de 600 mil) ${ }^{5}$ até o final de 2016, mais de 73 mil haitianos solicitaram refúgio no Brasil, sendo que apenas um teve a condição de refugiado reconhecida e cerca de 43 mil tiveram suas solicitações convertidas em vistos

\footnotetext{
${ }^{4}$ Importante mencionar que a imigração latino-americana para o Brasil também é relevante em termos numéricos. De 2010 à 2016, 3375 venezuelanos e 1370 cubanos solicitaram refúgio no Brasil (SECRETARIA NACIONAL DE JUSTIÇA, 2017). No que se refere aos nacionais de Estados-membros do MERCOSUL o Acordo Mercosul sobre residência para nacionais dos Estados partes do Mercosul e do Mercosul, Bolívia e Chile, ao qual recentemente aderiu também o Peru, tem beneficiado centenas de migrantes, podendo ser o germe de uma futura cidadania sul-americana. (grifo nosso)

${ }^{5}$ PIMENTEL e COTINGUIBA (2014) sustentam que o terremoto não foi a única causa propulsora da migração haitiana ao Brasil e informam que cerca de $46 \%$ dos haitianos que procuraram refúgio em nosso país não migraram de Porto Príncipe e região, local mais afetado pelo incidente. Referem os autores que: "O que consideramos a respeito do terremoto para esta migração é que o desastre pintou com cores de dramaticidade uma situação que se encontrava em curso diante de situações extremas. Assim, o terremoto dinamizou o que já era uma prática conhecida da sociedade haitiana, a emigração e o Brasil entrou na rota migratória por fatores diversos, como a rigidez para a entrada dessas pessoas em países como Estados Unidos, Canadá, França, além do agravamento de questões étnicas coma vizinha República Dominicana."
} 
humanitários (SECRETARIA NACIONAL DE JUSTIÇA, 2017), instituto regulamentado pela Resolução Normativa o 97 do CNlg, de 12 de janeiro de 2012, que estabeleceu o visto humanitário como instrumento da acolhida destinado aos nacionais do Haiti (BRASIL, 2012).

Diante de um quadro fático e normativo tão complexo, já que o obsoleto Estatuto do Estrangeiro, sem dar conta da nova realidade migratória do país, abriu brechas para uma vasta e fragmentada regulamentação infra legal da temática, a pressão da sociedade civil organizada ${ }^{6}$ - que sempre protagonizou o trabalho e a assistência a imigrantes - e de setores da academia, fez com que o governo federal, em 2013, iniciasse uma discussão sobre a possibilidade de revogação do Estatuto do Estrangeiro e a adoção de uma nova lei de migração que pudesse abandonar a doutrina da ideologia da segurança nacional e da proteção do mercado de trabalho interno para privilegiar a proteção dos direitos humanos dos migrantes estrangeiros em território nacional, bem como dos brasileiros residentes no exterior.

Em 2013, o Ministério de Justiça criou, então, uma comissão de especialistas para elaborar uma proposta de anteprojeto de Lei de Migrações e Promoção dos Direitos dos Migrantes no Brasil por meio da Portaria n 2.162/2013.

O anteprojeto foi elaborado com a participação de professores universitários, membros do Ministério Público, juristas e cientistas políticos, especialistas em direitos humanos, direito constitucional e direito internacional ${ }^{7}$, a partir de estudos sobre a legislação migratória brasileira, de outros países e de tratados internacionais; além da escuta de outros especialistas, de órgãos do governo e, sobretudo, da sociedade civil (MINISTÉRIO DA JUSTIÇA, 2014). O objetivo maior da nova lei era, pois, estabelecer

\footnotetext{
${ }^{6}$ Sobre a sociedade civil organizada, Reis aduz que "os movimentos sociais, organizações não governamentais e pesquisadores no Brasil ao longo dos anos buscaram não apenas sensibilizar o Estado brasileiro para as demandas dos emigrantes estrangeiros, como também construir um consenso sobre a importância das mudanças na lei de imigração brasileira e sua conexão com as demandas dos brasileiros no exterior". (REIS, 2011, p. 60)

${ }^{7}$ Os membros da Comissão de Especialistas, nomeados pela Portaria ${ }^{\circ}$ 2.162/2013, são: André de Carvalho Ramos (Professor da Faculdade de Direito da Universidade de São Paulo); Aurélio Veiga Rios (Procurador Federal dos Direitos do Cidadão); Clèmerson Merlin Clève (Professor da Faculdade de Direito da Universidade Federal do Paraná e da UniBrasil); Deisy de Freitas Lima Ventura (Professora do Instituto de Relações Internacionais da Universidade de São Paulo); João Guilherme Lima Granja Xavier da Silva (Diretor do Departamento de Estrangeiros do Ministério da justiça); José Luís Bolzan de Morais (Professor do Programa de Pós-graduação em Direito da Universidade do Vale do Rio dos Sinos); Paulo Abrão Pires Júnior (Secretario Nacional de Justiça do Ministério da Justiça); Pedro Bohomoletz de Abreu Dallari (Diretor do Instituto de Relações Internacionais da Universidade de São Paulo); Rossana Rocha Reis (Professora do Departamento de Ciência Política e do Instituto de Relações Internacionais da Universidade de São Paulo); Tarciso Dal Maso Jardim (Consultor Legislativo do Senado Federal) e Vanessa Oliveira Batista Berner (Professora da Faculdade Nacional de Direito da Universidade Federal do Rio de Janeiro).
} 
um marco regulatório de tratamento ao migrante fundamentado na proteção dos direitos humanos. Para tanto, era necessário o abandono da lógica estabelecida no Estatuto do Estrangeiro, tanto pela necessidade de adoção de uma lei compatível com a Constituição Federal e com os tratados internacionais de Direitos Humanos vigentes, como de mudanças paradigmáticas na política migratória, subordinada, até então, à lógica da segurança nacional e do controle documental voltado ao acesso do mercado de trabalho.

Uma das principais reivindicações da sociedade civil e dos migrantes era a criação de uma agência civil especializada para a regularização migratória, já que essas populações viam como essencial a desvinculação da recepção e regularização migratória das funções da Polícia Federal. Identificado o problema por Ventura e Illes (2012), os autores discorrem sobre as consequências nefastas da ausência de um órgão civil na prática cotidiana de recepção de migrantes no Brasil:

\begin{abstract}
O Brasil não dispõe de um serviço de imigração (civil). Para requererem a regularização de sua situação, os migrantes devem dirigir-se à Polícia Federal, cujos serviços são em grande parte terceirizados, desprovidos de formação e mal remunerados. É importante acrescentar que a polícia tende a uma interpretação restritiva das normas que beneficiam os migrantes. Ao buscar a regularização, o migrante, não raro, encontra um calvário, com a exigência de documentos que sabidamente ele não tem condições de apresentar. Num círculo vicioso, a constância da irregularidade gera mais precariedade. Para além das deficiências de atendimento, é preciso entender também que as polícias ainda penam para superar o paradigma da segurança nacional, sucedido pelo ideário da "guerra ao terror", altamente xenófobo, preconizado pelos Estados Unidos e seus parceiros após os atentados de 11 de setembro de 2001. (grifo nosso)
\end{abstract}

Após o levantamento das principais reivindicações das populações migrantes, da sociedade civil organizada e de acadêmicos ${ }^{8}$, a Comissão apontou a necessidade de revogação da Lei n 6.815/80, pois se tratava de uma "herança da ditadura civil-militar" (MINISTÉRIO DA JUSTIÇA, 2014), que proibia ao estrangeiro exercer atividade de natureza política; organizar, criar ou manter sociedade ou

\footnotetext{
${ }^{8} \mathrm{~A}$ Comissão recebeu mais de duas dezenas de contribuições escritas de entidades públicas e sociais: Associação Brasileira de Antropologia - ABA, Alto Comissariado das Nações Unidas para os Refugiados - ACNUR Brasil, Casa das Áfricas, CARITAS Brasil, CARITAS de São Paulo, Centro de Atendimento ao Migrante de Caxias do Sul (RS), Centro de Estudios Legales y Sociales - CELS, CONECTAS Direitos Humanos, Conferência Livre de Santa Maria (RS) - preparatória da COMIGRAR, Defensoria Pública da União, Fórum Social Pelos Direitos Humanos e Integração dos Migrantes no Brasil, Coordenação de Políticas para Imigrantes da Secretaria Municipal de Direitos Humanos e Cidadania de São Paulo, Grupo de Estudos Migratórios e Assessoria ao Trabalhador Estrangeiro - GEMTE, Instituto de Migrações e Direitos Humanos - IMDH, Instituto Terra, Trabalho e Cidadania, Ministério Público do Trabalho, Presença América Latina e Rede Sul Americana para as Migrações Ambientais - RESAMA; também recebeu contribuições escritas individuais de migrantes e de especialistas, além de levar em consideração os comentários da Secretaria de Assuntos Legislativos do Ministério da Justiça - SAL/MJ;
} 
quaisquer entidades de caráter político; organizar desfiles, passeatas, comícios e reuniões de qualquer natureza, ou deles participar (artigo 107); ser representante de sindicato ou associação profissional, ou de entidade fiscalizadora do exercício de profissão regulamentada (artigo 106); possuir, manter ou operar, mesmo como amador, aparelho de radiodifusão, de radiotelegrafia e similar; ou ainda prestar assistência religiosa a estabelecimentos de internação coletiva (artigo 106). De outro lado, permitia ao ministro da justiça, sempre que considerasse conveniente aos interesses nacionais, impedir a realização, por estrangeiros, de conferências, congressos e exibições artísticas ou folclóricas (artigo 110). Medidas como essas se tornaram flagrantemente inconstitucionais depois da promulgação da Constituição Federal de 1988, por violarem o art. 5, incisos IV, VI, XVI e XVII da CF/88, que garantem a liberdade de expressão, de crença, de reunião e associação para fins pacíficos de brasileiros e estrangeiros presentes no país. Além disso, outras medidas previstas no Estatuto violavam o princípio do contraditório e da ampla defesa em processos de expulsão de imigrantes do território brasileiro. $\mathrm{O}$ art. 65 , por exemplo, previa a possibilidade de expulsão de imigrantes com base em conceitos bastante abstratos como atentar contra "a tranquilidade ou moralidade pública e a economia popular, ou cujo procedimento o torne nocivo à conveniência e aos interesses nacionais; entregar-se à vadiagem ou à mendicância"9.

Com o fito de fundamentar uma futura lei de migração em princípios de proteção dos direitos humanos da população migrante, a comissão entendia que os principais temas a serem enfrentados pelo anteprojeto deveriam ser: (i) o abandono da ideologia securitária que embasava o Estatuto do Estrangeiro; (ii) o encorajamento da regularização migratória através da desburocratização dos processos de permissão de entrada e concessão de residência no país; (iii) a inclusão da proteção aos emigrantes e migrantes transitórios na lei; (iv) o direito à residência mediante o atendimento das condições previstas em lei, permitindo inclusive a reunião familiar; $(v)$ desvinculação da regularização migratória da prova de emprego formal, permitindo que imigrantes possam vir ao país na busca de empregos e; (vi) a criação de um órgão estatal especializado para atendimento dos migrantes, retirando da Polícia Federal a

\footnotetext{
${ }^{9}$ Relevante informar que o art. 60 do Decreto-Lei 3.688/1940 (Lei de Contravenções Penais) foi revogado pela Lei 11.983, de 17 de julho de 2009, fazendo com que a conduta de mendicância (Mendigar, por ociosidade ou cupidez: Pena - prisão simples, de 15 (quinze) dias a 3 (três) meses. Parágrafo único Aumenta-se a pena de um sexto a um terço, se a contravenção é praticada: a) de modo vexatório, ameaçador ou fraudulento; b) mediante simulação de moléstia ou deformidade; c) em companhia de alienado ou de menor de 18 (dezoito) anos), deixasse de ser típica no direito brasileiro.
} 
competência para a recepção e regularização de imigrantes no Brasil (MINISTÉRIO DA JUSTIÇA, 2014).

A primeira versão do anteprojeto foi finalizada e difundida nos meses de abril e maio de 2014, a seguir foi submetida à discussão em audiências públicas. Nesse processo, a comissão recebeu mais de duas dezenas de sugestões de entidades públicas e sociais. Em um segundo momento, a comissão recebeu recomendações da I Conferência Nacional sobre Migrações e Refúgio - COMIGRAR (que será objeto de análise a seguir), ocorrida entre 30 de maio e $1^{\circ}$ de junho de 2014, em São Paulo (MINISTÉRIO DA JUSTIÇA, 2014).

Ao final do processo de elaboração do anteprojeto, a comissão apontou cinco características da proposta de elaboração da nova lei. Em primeiro lugar, a necessidade de harmonização da lei aos princípios de igualdade trazidos pela $\mathrm{CF} / 88$, bem como o imperativo de respeito aos compromissos de proteção de direitos humanos assumidos pelo Brasil no plano internacional. Em segundo lugar, uma mudança paradigmática, deslocando o tema das migrações das políticas de segurança nacional e realocando-o no tema da proteção dos Direitos Humanos. Em terceiro, o enfrentamento da fragmentação dos avanços normativos infra legais empreendidos pelo Brasil em matéria de regulação migratória, com o objetivo de dotar a ordem jurídica pátria de coerência sistêmica. Em quarto, elemento crucial da consolidação da democracia brasileira, o anteprojeto acolheu demandas históricas de entidades sociais que atuam em defesa dos direitos dos migrantes, sendo a mais relevante, a criação de uma autoridade civil para a recepção e regularização migratória no país. E, por fim, a desburocratização dos processos de regularização migratória como exigência para a construção e manutenção de rotas seguras de migração (MINISTÉRIO DA JUSTIÇA, 2014).

Apesar da ampla participação popular garantida no processo de elaboração da nova lei de migração, o anteprojeto não foi submetido ao Congresso, tendo sido substituído pelo projeto de lei 288/2013 de autoria do Senador Aloysio Nunes, que já tramitava no Senado desde 11 de julho de 2013 (OLIVEIRA, 2017).

\subsection{A COMIGRAR e a participação da sociedade civil na elaboração do novo marco legal}


O Brasil, de acordo com o art. $1^{\circ}$ da CF/88, prevê que "todo o poder emana do povo que o exerce por meio de representantes eleitos ou diretamente", consagrando um modelo de democracia representativa e o princípio da participação popular como forma de afirmação da democracia direita. Porém, em um país no qual o imigrante não é considerado cidadão, pelo menos sob a perspectiva dos direitos políticos, que lhes são negados pela $\mathrm{CF} / 88^{10}$, a possibilidade de participação ativa que essa população teve na elaboração do marco regulatório que revogaria o Estatuto do Estrangeiro se materializou por meio da realização da $1^{\text {a }}$ Conferência Nacional sobre Migrações e Refúgio (COMIGRAR), que representou uma importante inversão da lógica de denegação de direitos políticos à qual os imigrantes foram recorrentemente submetidos no Brasil.

Naquele contexto, ainda que de forma limitada e pontual, os imigrantes puderam fazer parte ativamente de um espaço político que envolvia o processo de construção normativa ao qual estariam submetidos a partir de então, e, convertendose em destinatários de prestações civilizatórias do Estado, para utilizar uma das categorias teóricas desenvolvidas por Friedrich Müller sobre as múltiplas formas de se conceber a expressão "povo"11.

A COMIGRAR, realizada em 30 de maio e $1^{\circ}$ de junho de $2014^{12}$, foi uma iniciativa governamental inovadora na abordagem da questão migratória no Brasil. Ocorreu a partir da mobilização nacional e internacional dos diversos atores

\footnotetext{
${ }^{10} \mathrm{~A} \mathrm{CF} / 88$ não igualou o imigrante ao cidadão brasileiro, pois o artigo $14, \S 3^{\circ}$, I da Carta exige nacionalidade brasileira para o alistamento eleitoral, proibindo, assim, que imigrantes exerçam direitos políticos (eleitorais) no país (BRASIL, 1988). Nesse sentido, Ventura e llles (2012) sustentam que a anacrônica negação constitucional do exercício dos direitos políticos aos migrantes coloca o Brasil em um local isolado "num continente em que o direito ao voto dos migrantes já foi reconhecido por Argentina, Bolívia, Colômbia, Equador, México e Peru".

${ }^{11}$ Müller, ao se debruçar sobre o conceito de povo nas democracias contemporâneas, na obra Quem é o povo? estabelece quatro categorias que explicam o fenômeno: o povo ativo, entendido como aquele formado por pessoas com direitos políticos e no uso destes e que, dessa maneira, podem eleger seus representantes, ser eleitos, propor matérias de iniciativa popular e votar em consultas populares; o povo como instância global de atribuição de legitimidade, que aparece a partir do momento em que o ordenamento construído conforme a vontade das leis promulgadas por um corpo eleito é respeitado e adquire um sentido geral de legitimidade dentro da generalidade dos cidadãos do Estado; o povo como ícone, que representa a degeneração do sentido anterior, aparecendo quando a vontade popular não é respeitada pelas instituições e o povo é usado como mero artifício discursivo para atribuição de legitimidade; e o povo como destinatário de prestações civilizatórias do Estado, que pode ser entendido como o conjunto de pessoas que, ao se submeterem à jurisdição de um Estado, tem direito a prestações essenciais para sua sobrevivência digna, isto é, os Direitos Humanos e Fundamentais. (2003, pp. 4563)

${ }^{12} \mathrm{~A}$ COMIGRAR foi organizada pela Secretaria Nacional de Justiça e pelo Departamento de Estrangeiros do Ministério da Justiça, com a participação do Ministério do Trabalho e Emprego e o Ministério das Relações Exteriores e apoio da Organização Internacional para Migrações (OIM) e do Programa das Nações Unidas para o Desenvolvimento (PNUD).
} 
interessados no tema e na discussão dos conceitos centrais da política migratória, com a intenção de se produzir um material, a partir do debate dos mais diversos setores da sociedade, com protagonismo do migrante, para subsidiar a elaboração de um novo marco legal migratório no Brasil.

O trabalho de preparação para a COMIGRAR iniciou no ano de 2013 através da coordenação da Secretaria Nacional de Justiça. Foram estabelecidas três tipos de conferências participativas preparatórias ${ }^{13}$ para a conferência nacional: conferências estaduais e municipais, que deveriam elaborar propostas, bem como eleger delegados para a participação na etapa nacional; conferências livres, promovidas por qualquer grupo articulado de pessoas ou organização de qualquer segmento ligado à temática migratória (associações, universidades, coletivos, instituições religiosas, etc), que poderiam indicar delegados e submeter propostas para a COMIGRAR nacional; e a conferência virtual na qual, a partir de uma plataforma on line ${ }^{14}$, todas as pessoas poderiam submeter propostas e debatê-las virtualmente. Foram realizadas, entre 2013 e 2014, 202 conferências preparatórias (9 virtuais, 23 governamentais e 170 livres), com o envolvimento direto de mais de 5 mil pessoas, dentre elas: migrantes, acadêmicos, sociedade civil organizada e agentes públicos (SECRETARIA NACIONAL DE JUSTIÇA, 2014d, p. 1). Todo o material produzido pelas conferências preparatórias, cerca de 2.640 propostas levantadas pelos participantes, foi sistematizado em 15 eixos a serem analisados e votados pelos delegados na etapa nacional da COMIGRAR.

Dentre os temas abordados e discutidos na oportunidade, podem ser citados: revogação do marco legal representado pelo Estatuto do Estrangeiro e modificação constitucional permitindo o direito ao voto aos imigrantes; criação de órgão nacional especializado e responsável pelos temas de migração e refúgio, na forma de ministério, secretaria, agência reguladora ou autarquia, vinculado à Presidência da República ou à Secretaria Especial de Direitos Humanos; habilitação de equipamentos públicos como Centros de Referência de Assistência Social (CRAS), Centros de Referência

\footnotetext{
${ }^{13} \mathrm{O}$ processo participativo de implementação da $1^{\circ}$ COMIGRAR previu a realização de eventos preparatórios e de mobilização dos atores locais que conviviam com diferentes enfoques da temática migratória. Tais eventos foram oportunidades para promover a reflexão e o fortalecimento institucional de parceiros governamentais e não governamentais, além do engajamento de migrantes e representantes da sociedade no diálogo em torno dos temas migratórios (SECRETARIA NACIONAL DE JUSTIÇA, 2014c, p. 4).

${ }^{14}$ A Secretaria-Geral da Presidência da República criou o ambiente virtual do "Participa Brasil", http://participa.br/, como parte da Política Nacional de Participação Social e espaço de diálogo entre o governo e a sociedade civil.
} 
Especializado de Assistência Social (CREAS), Postos de Saúde, Centros de Referência LGBT, Centros de Referência da Mulher para atuarem como portas de orientação e acolhimento a migrantes e refugiados; capacitação de agentes públicos para o atendimento e recepção de imigrantes e refugiados nos mais diversos setores da sociedade; desburocratização e uniformização em nível nacional de todos os procedimentos administrativos de concessão, extensão e alteração de visto, solicitação de refúgio, interposição de recursos, e demais procedimentos pertinentes referentes à emissão e renovação de documentos entre outros, por meio de medidas específicas; promoção do direito do trabalho decente aos migrantes, independentemente de sua situação migratória; acesso à justiça com atendimento em Defensorias Públicas; acesso ao Sistema Único da Saúde e a políticas e programas sociais disponíveis a brasileiros (CLARO; FAUTH, 2015, p. 90).

Considerando o resultado do amplo processo participativo promovido pela COMIGRAR, em 2014, Claro e Fauth (2015, p. 91) suscitaram o impacto que as recomendações surgidas na Conferência teriam, futuramente, sobre o planejamento e a condução das políticas públicas sobre migrações no Brasil e a sua possível influência ou não na elaboração e aprovação de uma nova legislação sobre migrações no Brasil. Aprovada a Lei 13.445 em 2017, já é possível fazer essa análise.

\section{NOVA LEI DE MIGRAÇÃO: AVANÇOS E LIMITES DO NOVO MARCO LEGAL}

\subsection{O resultado da luta pela revogação do Estatuto do Estrangeiro: avanços e limites}

O novo marco legal migratório, inaugurado pela Lei ํㅗ $13.445 / 17$, que entrou em vigor em 21 de novembro de 2017, se fundamentou principalmente no Projeto de Lei 288/13, de autoria do Senador Aloysio Nunes. O trabalho realizado pela comissão de especialistas, criada em 2013, e o material produzido na COMIGRAR foram utilizados apenas incidentalmente em modificações que o PL 288/13 sofreu ao longo do processo legislativo (MIGRAMUNDO, 2016). Uma das principais diferenças entre os dois projetos se relaciona justamente com um dos temas mais caros aos imigrantes no Brasil, qual seja, a necessidade de criação de uma autoridade civil encarregada de recepção e regularização migratória no país. $O$ anteprojeto da comissão contemplava essa demanda, enquanto o PL 288/13 estabeleceu a manutenção da competência da Polícia Federal no controle migratório e de fronteiras no país. 
Apesar do discurso adotado pelo autor e relator da nova Lei, de que o fundamento maior do instrumento se daria na proteção dos direitos da pessoa migrante, causa estranhamento o fato de o PL 288/13 não ter passado pela análise da Comissão de Direitos Humanos, exigência do Regimento Interno do Senado, em seu art. 102-E, inciso VII, que determina taxativamente que temas relativos aos direitos dos estrangeiros devem passar pela Comissão de Direitos Humanos e Legislação Participativa (SENADO FEDERAL, 2015). Foi submetido apenas ao crivo da Comissão de Assuntos Sociais, de Constituição, Justiça e Cidadania e de Relações Exteriores e Defesa Nacional, essa última apresentando um substitutivo que apresentou inovações importantes sob a influência do anteprojeto da Comissão de especialistas (MORAES, 2015), com destaque para a necessidade de revogação completa do Estatuto do Estrangeiro, a substituição do termo estrangeiro por migrante ${ }^{15}$ e a inclusão das categorias de migrante temporário, residente fronteiriço, apátrida e emigrante brasileiro, incluindo um título exclusivo dedicado a essa última (SENADO FEDERAL, 2017).

A aprovação da Lei oㅜ 13.445/17 (Nova Lei de Migração Brasileira) foi celebrada por muitos pesquisadores e operadores afeitos ao tema das migrações e por representantes da sociedade civil, mas também recebeu críticas no que se refere às limitações de seu texto. $O$ instrumento foi aprovado com o condão de abandonar definitivamente a sujeição do imigrante a políticas de segurança nacional e interesses nacionais relativos à proteção do mercado de trabalho interno e adotar uma fundamentação baseada na proteção dos Direitos Humanos da pessoa migrante.

Para autores como Guerra (2017), "indubitavelmente a nova lei coloca o Brasil em posição de vanguarda nesta matéria, posto que defere aos imigrantes uma série de prerrogativas que até então eram conferidos apenas para os seus nacionais". Dentre os avanços, destacou a desburocratização do processo de regularização migratória, a institucionalização da política de vistos humanitários e a não criminalização dos indivíduos por razões migratórias. No mesmo sentido, Asano e Timo (2017) avaliaram de forma positiva a aprovação na nova Lei de Migrações, sobretudo pelo fato de que o ano anterior à aprovação "foi marcado por retrocessos legislativos na pauta dos direitos humanos".

\footnotetext{
${ }^{15}$ No que se refere ao conceito de migrante ou estrangeiro, sempre importante lembrar que qualquer pessoa já migrou ou pode migrar um dia. O estrangeiro é um estado passageiro, não a essência de uma pessoa. "No fundo, o estrangeiro não existe, ou somos nós mesmos, por vezes até em nossa pátria" (VENTURA e ILLES, 2012). Nesse sentido ver também: PEREIRA, Gustavo Oliveira de Lima. Direitos Humanos e Hospitalidade. Porto Alegre. Atlas, 2014. p. 72.
} 
Gersztein (2017) afirmou também que, desde um ponto de vista simbólico, "ser intitulada como 'Lei de Migração' já é algo bastante significativo, pois demonstra a compreensão de que migrar é um direito humano em contraposição à normativa que impõe aos 'estrangeiros' um 'estatuto' bastante limitador".

De fato, há que se reconhecer que diferentemente do Estatuto do Estrangeiro, a nova Lei de Migração trata o imigrante como um sujeito de direitos e garante em todo o território nacional, a condição de igualdade com os nacionais, desembocando em uma série de direitos que anteriormente não eram concebidos, a saber: a inviolabilidade do direito à vida, à liberdade, à igualdade, à segurança e à propriedade; liberdades civis, sociais, culturais e econômicos; liberdade de circulação em território nacional; reunião familiar do imigrante com seu cônjuge ou companheiro e seus filhos, familiares e dependentes; medidas de proteção a vítimas e testemunhas de crimes e de violações de direitos; transferência de recursos decorrentes de sua renda e economias pessoais a outro país, observada a legislação aplicável; reunião para fins pacíficos; associação, inclusive sindical, para fins lícitos; acesso a serviços públicos de saúde e de assistência social e à previdência social, nos termos da lei; amplo acesso à justiça e à assistência jurídica integral gratuita aos que comprovarem insuficiência de recursos; educação pública; garantia de cumprimento de obrigações legais e contratuais trabalhistas e de aplicação das normas de proteção ao trabalhador, sem discriminação em razão da nacionalidade e da condição migratória; isenção das taxas de que trata esta Lei, mediante declaração de hipossuficiência econômica, na forma de regulamento; acesso à informação e garantia de confidencialidade quanto aos dados pessoais do imigrante, nos termos da Lei no 12.527, de 18 de novembro de 2011; abertura de conta bancária; sair, permanecer e reingressar em território nacional, mesmo enquanto pendente pedido de residência, de prorrogação de estada ou de transformação de visto em residência; e ser informado sobre as garantias que the são asseguradas para fins de regularização migratória.

No que se refere aos direitos de liberdade, consagrados na nova Lei de Migração, há que se fazer um destaque especial à adequação do texto legal ao conteúdo constitucional que garante desde 1988 a brasileiros e estrangeiros o direito a livre manifestação do pensamento, direito de reunião para fins pacíficos e direito de associação, pois tais direitos, conforme supramencionado, eram expressamente proibidos pelo Estatuto do Estrangeiro, evidenciando o descompasso e anacronismo do instrumento após a promulgação da CF/88. 
Ainda que possa parecer redundante o texto da nova Lei de Migração incluir direitos já constantes na $\mathrm{CF} / 88$, mostrou-se de suma importância que, em um cenário histórica e culturalmente marcado pela criminalização e perseguição de imigrantes, o texto legal específico sobre o tema contemplasse - ainda que de forma repetitiva - o conjunto de direitos constitucionais a que gozam todas as pessoas em situação de migração. Contudo, como já foi exemplificado anteriormente, não era incomum que agentes do Estado brasileiro fundamentassem suas ações em dispositivos inconstitucionais do Estatuto do Estrangeiro, violando direitos garantidos pela CF/88 aos migrantes; o que torna a repetição uma necessidade.

No que se refere à garantia de direitos sociais aos migrantes, a nova Lei prevê inclusão social, laboral e produtiva do migrante por meio de políticas públicas; acesso igualitário e livre a serviços, programas e benefícios sociais, bens públicos, educação, assistência jurídica integral pública, trabalho, moradia, serviço bancário e seguridade social.

Com relação à admissão e às medidas de retirada compulsória dos migrantes do território nacional, a nova Lei procurou adotar critérios objetivos para limitar a discricionariedade do Estado nessas situações. Guerra (2017) lembra que "é de competência exclusiva de cada Estado legislar sobre a admissão e expulsão de estrangeiros em sua base física", entretanto, a nova Lei "procura apresentar critérios objetivos que garantem, de forma mais satisfatória a proteção jurídica ao não nacional". Ademais, requisitos como a "satisfação das condições de saúde estabelecidas pelo Ministério da Saúde" e o não enquadramento como indivíduos "nocivos à ordem pública ou aos interesses nacionais" (art. $7^{\circ}$ ) exigidos para a concessão de vistos pelo Estatuto do Estrangeiro, foram abandonados pela nova Lei.

Quanto ao acesso à justiça nos processos de retirada compulsória (deportação, expulsão e extradição), os arts. 51 e 58 da Lei preveem a garantia do contraditório e da ampla defesa aos réus e obrigatória notificação da Defensoria Pública da União, no momento da instauração dos procedimentos. Durante o andamento dos processos de retirada compulsória a situação do migrante em território nacional permanece regular, exigência do princípio da não criminalização das migrações.

Outra inovação positiva trazida pela nova Lei foi a instituição, por via legal, da acolhida humanitária, que desde 2012 era regulamentada pelas Resoluções 
Normativas n. 97 e n. 102 do $C N l^{16}{ }^{16}$, passíveis de revogação por órgão administrativo, o que deixava os milhares de imigrantes que haviam sido beneficiados por esse instrumento em uma situação de insegurança jurídica, pois podia ser revogado a qualquer tempo pelo Executivo. Assim, o art. 14, $\S 3^{\circ}$ da nova Lei estabelece que:

O visto temporário para acolhida humanitária poderá ser concedido ao apátrida ou ao nacional de qualquer país em situação de grave ou iminente instabilidade institucional, de conflito armado, de calamidade de grande proporção, de desastre ambiental ou de grave violação de direitos humanos ou de direito internacional humanitário, ou em outras hipóteses, na forma de regulamento. (BRASIL, 2017)

Essa previsão põe fim a um limbo legal de proteção a pessoas que não se enquadram na definição de refúgio do art. $1^{\circ}$ da Lei oํ 9.474/97 e aquelas que não preenchiam os requisitos de regularização migratória ordinários, previstos no Estatuto do Estrangeiro ${ }^{17}$.

Por fim, impende citar a proteção aos apátridas prevista pela nova Lei. O art. 26 do instrumento garante às pessoas que não possuem nacionalidade a facilitação do processo de aquisição de nacionalidade secundária no Brasil.

Todos esses avanços, em momentos de retrocesso da proteção aos direitos humanos no país, fizeram com que a nova Lei de Migração fosse festejada pelos setores envolvidos com o tema há décadas no Brasil. Ainda assim, a Lei foi omissa em pontos importantes que faziam parte das demandas dos imigrantes e da sociedade civil e foram inseridas nas propostas da COMIGRAR. A principal omissão se refere a não previsão da criação de uma autoridade migratória civil, que desvinculasse da competência da Polícia Federal a recepção e regularização do migrante, já que o art. 117 do PL 288/13, que previa a criação do órgão por influência do anteprojeto da comissão de especialistas, foi retirado do texto final aprovado, por apresentar vício de inciativa. O relator do Projeto, Senador Tasso Jereissati, afirmou que "Trata-se de um projeto de origem do Senado Federal, que não pode criar um órgão dessa natureza, já que encerra conteúdo sobre organização e funcionamento da administração federal e, por via de consequência, invade competência privativa da Presidência da República".

\footnotetext{
${ }^{16}$ Resolução Normativa $n^{\circ} 97$ : Ao nacional do Haiti poderá ser concedido o visto permanente previsto no art. 16 da Lei no 6.815, de 19 de agosto de 1980, por razões humanitárias, condicionado ao prazo de 5 (cinco) anos, nos termos do art. 18 da mesma Lei, circunstância que constará da Cédula de Identidade do Estrangeiro. Parágrafo único. Poderão ser concedidos até 1.200 (mil e duzentos) vistos por ano, correspondendo a uma média de 100 (cem) concessões por mês, sem prejuízo das demais modalidades de vistos previstas nas disposições legais do País (Revogado pela Resolução Normativa $\mathrm{n}^{\circ} 102$ do CNIg).

${ }^{17}$ Situação em que se encontravam os nacionais do Haiti quando iniciaram um fluxo contínuo de migração para o Brasil, em 2010.
} 
De fato, o art. 81, V, atribui ao Presidente da República competência para "dispor sobre a estruturação, atribuições e funcionamento dos órgãos da administração federal”. Há também o art. 61, $\S 1^{\circ}$, I, e, que prevê que criação e extinção de Ministérios e órgãos da administração pública é de competência do Presidente da República.

Contudo, se o projeto apresentado tivesse sido o da comissão de especialistas, formada pelo Ministério da Justiça, esse vício não existiria, uma vez que muito provavelmente o projeto teria chegado ao Congresso Nacional como sendo de inciativa da Presidência da República. Naturalmente, a não consideração do anteprojeto da comissão foi um duro golpe a todas as entidades que haviam se engajado fortemente no processo de construção de um novo marco legal migratório. E, diante dessa consideração, se o poder executivo atual tivesse tido um mínimo de comprometimento político com a sociedade civil organizada, que tinha na questão da criação de uma autoridade migratória civil uma prioridade, isso poderia ter sido evitado e o principal símbolo de superação da lógica anterior de tratamento das pessoas migrantes estaria superado.

O processo legislativo de aprovação da nova Lei de Migração Brasileira culminou, em 25 de maio de 2017, com a sanção presidencial, que impôs dezenas de vetos ao instrumento, descaracterizando, em parte, sua fundamentação na proteção dos direitos humanos da pessoa migrante e concedendo novamente discricionariedade extrema ao Estado na admissão e regularização desses indivíduos em território nacional. Alguns dos vetos mais importantes e motivações serão analisados a seguir.

\subsection{Vetos do poder executivo: os retrocessos impostos à nova Lei de Migração Brasileira}

Da análise feita até aqui, pode-se inferir que o novo marco regulatório sobre migrações representou avanços no cenário político brasileiro, apesar das omissões do projeto de lei e da ausência de continuidade de participação popular, iniciada pela COMIGRAR, no processo de debates e deliberação da Lei 13.445. Contudo, as limitações apontadas até aqui adquirem um novo significado quando colocadas ao lado dos 18 vetos presidenciais sofridos pelo novo texto legal, que de forma não surpreendente ${ }^{18}$ indicam a retomada da anacrônica lógica da segurança nacional. $\mathrm{Na}$

${ }^{18}$ Os vetos feitos na Lei $13.445 / 17$ não surpreendem porque fazem parte de uma conjuntura protagonizada pelo atual ocupante formal do cargo de presidente da república no Brasil com a concordância da maioria do Congresso Nacional de ataques à pauta dos direitos humanos, como a reforma trabalhista, 
análise de Gersztein (2017), os vetos foram "impostos por ação do Poder Executivo e omissão do Poder Legislativo demonstrando visão calcada em uma ideia de 'soberania nacional' que considera o imigrante como um estranho, uma ameaça, alguém que a qualquer momento poderá 'trair os interesses nacionais". Nesse sentido, cumpre mencionar que a tentativa de abandono da ideologia securitária e protecionista pela nova Lei de Migração restou prejudicada.

A lista de vetos inicia com o próprio conceito de migrante (art. $1^{\circ}$, $\S 1^{\circ}$ ), ou seja, a "pessoa que se desloca de país ou região geográfica ao território de outro país ou região geográfica, incluindo o imigrante, o emigrante, o residente fronteiriço e o apátrida". A justificativa do veto informa que "O dispositivo estabelece conceito demasiadamente amplo de migrante, abrangendo inclusive o estrangeiro com residência em país fronteiriço, o que estende a todo e qualquer estrangeiro, qualquer que seja sua condição migratória, a igualdade com os nacionais, violando a Constituição em seu artigo 5을 que estabelece que aquela igualdade é limitada e tem como critério para sua efetividade a residência do estrangeiro no território nacional".

Primeiramente, salta aos olhos a insistência na utilização da expressão "estrangeiro", depois, o conceito de migrante adotado em tratados e convenções internacionais, como a Convenção Internacional sobre a Proteção dos Direitos de Todos os Trabalhadores Migrantes e dos Membros das suas Famílias de 1990, prevê a existência de migrantes fronteiriços (art. $2^{\circ}$ ), não discriminando essas pessoas em relação aos demais migrantes. No que se refere à segunda parte da justificativa, a interpretação que se dá, no veto, ao caput do artigo $5^{\circ}$ é equivocada e desconhece a realidade dos processos migratórios. $\mathrm{O}$ que é um residente fronteiriço senão aquele que em determinadas circunstâncias também residirá no nosso território?

Também sofreu veto 0 trecho da lei ( $\S 10$ do art. 14) que permitia 0 estabelecimento, por regulamento, de novos casos de vistos temporários, sob a justificativa de demasiada ampliação do instituto do visto temporário com base na "insegurança jurídica" e em uma "discricionariedade indevida" por parte do Estado, invocadas nessa situação de modo muito conveniente, já que a regulamentação do visto temporário com definição de categorias, condições e prazos nada mais representaria do que a ampliação desse direito dentro de uma lógica de proteção das

o congelamento dos gastos públicos com políticas sociais, a proposta de reforma da previdência social e a intervenção militarizada no Estado do Rio de Janeiro. A imposição de vetos ao novo marco legal sobre migrações bem como o conteúdo de decreto 9.199/17 de regulamentação da Lei são apenas mais um conjunto de retrocessos democráticos em relação ao processo de conquista de direitos no Brasil, que nos conduz ao autoritário pré Estado de Direito vivido nos tempos do regime militar. 
pessoas em situação de migração. Contudo, na contra lógica da doutrina da segurança nacional, como demonstrado anteriormente, essa ampliação tem um significado sempre ameaçador e, em tempos de democracia disfarçada, nada mais interessante do que a invocação da insegurança jurídica e dos próprios perigos da atuação discricionária do Estado para barrar a suposta "ameaça futura".

Em excelente análise, Gersztein (2017) desconstrói esse argumento desmascarando a diferença entre discricionariedade e arbitrariedade, demonstrando que "um 'ato discricionário indevido' seria aquele praticado em detrimento da lei, uma ilegalidade". A concessão de vistos por meio de regulamento, já que permitido pela Lei, seria um ato legal e desejável. Foi por meio de instituto similar, inclusive, que foram concedidos a milhares de cidadãos haitianos vistos humanitários para ingressar e permanecer em território brasileiro, ainda que não se enquadrassem nas categorias ordinárias de vistos previstas pelo Estatuto do Estrangeiro ${ }^{19}$. Assim também entendem Vedovato e Assis (2018), para quem a discricionariedade, nesse caso, seria benéfica, pois atuaria no sentido de se garantir maior proteção a pessoas que, por ventura, se encontrassem em situação de vulnerabilidade não prevista pela lei.

O artigo 37, parágrafo único da Lei, que previa que "a concessão de visto ou de autorização de residência para fins de reunião familiar poderá ser estendida, por meio de ato fundamentado, a outras hipóteses de parentesco, dependência afetiva e fatores de sociabilidade", também foi vetado em razão de uma possibilidade abstrata de "sequestro internacional de menores". Em primeiro lugar, importa ressaltar que tanto do ponto de vista internacional, quanto interno, o princípio do melhor interesse do menor se aplica em todos os casos nos quais estejam envolvidos. Nesse sentido, impende referir que a possibilidade de reunião familiar do menor com sua família, quer seja a família consanguínea ou afetiva, deve ser facilitada e não dificultada. As famílias constituídas pelo laço de afetividade são protegidas pela CF/88. Nessa perspectiva, Dias (2010) afirma que "a nenhuma espécie de vínculo que tenha por base o afeto se pode deixar de conferir o status de família, merecedora da proteção do Estado, pois a Constituição Federal, no inc. III do art. $1^{\circ}$, que consagra, em norma pétrea, o respeito à dignidade da pessoa humana". O remédio contra a possibilidade de sequestro internacional de menores já havia sido previsto na Lei pela exigência do necessário "ato fundamentado" como requisito para a concessão do visto.

\footnotetext{
${ }^{19}$ Conforme referido supra, o CNIg, em Resolução Normativa $n^{\circ} 27$, previa a criação de novas modalidades
} de visto em casos de omissão do Estatuto do Estrangeiro. 
Outro ataque ao sentido humanista pretendido durante a elaboração da Lei ocorreu com os vetos aos incisos I e IV do artigo 66, que reduziam para um ano (em relação ao período ordinário de quatro anos) o prazo para a naturalização de pessoas originárias de países de língua portuguesa e naturais de países do MERCOSUL. Como justificativa, a presidência alegou que:

Ao não exigir o critério de reciprocidade no processo simplificado de naturalização, instituto cuja consequência é o direito político, de votar e ser votado, o dispositivo teria o condão de ampliar o exercício da cidadania brasileira, podendo fragilizar o processo eleitoral nacional e introduzir elementos com efeitos imprevisíveis sobre a democracia do País.

Apenas a lógica de que o "estrangeiro" é o estranho inimigo justifica uma explicação de tal nível. Com efeito, as razões do veto supramencionado são injustificadas. No que se refere aos cidadãos provenientes de Portugal, por exemplo, esses já exercem direitos políticos no Brasil a partir de um ano de residência permanente por força do Estatuto da Igualdade consagrado constitucionalmente entre brasileiros e portugueses ${ }^{20}$. Ademais, causa espanto que em um Estado Democrático de Direito um dispositivo que venha para "ampliar o exercício da cidadania brasileira" possa ser vetado por risco de "fragilização do processo eleitoral nacional". Toda a construção teórica sobre democracia constitucional, em autores como Müller (1990), por exemplo, se fundamenta na necessidade de ampliar os processos que legitimam o poder do Estado, a partir de um aumento formal e material da participação democrática daqueles que serão os destinatários das prestações estatais, o que inclui os migrantes ${ }^{21}$. Gersztein (2017) resume bem o absurdo do veto imposto ao artigo 66 quando aduz que:

[...] iii) a ampliação do exercício da cidadania brasileira constitui, segundo a lógica expressa nas razões de veto, uma fragilização do processo eleitoral (!), o que demonstra - e a história não se furta a nos demonstrar inúmeros exemplos disso - que segundo uma visão autoritária reconhecer àqueles que compõem uma comunidade a possibilidade de participar das decisões que repercutirão em suas vidas pode fragilizar um processo que, per si, deve(ria) existir essencialmente para garantir justamente essa participação; iv) a citada possibilidade de ampliação da cidadania ensejaria

\footnotetext{
${ }^{20}$ Art. $12, \S 2^{\circ}$ da CF.

${ }^{21}$ No que se refere ao tema dos direitos políticos dos imigrantes no Brasil, a CF/88, no artigo 14, estabelece que apenas brasileiros natos e naturalizados têm capacidade eleitoral ativa e passiva no país, excluindo aos migrantes essa possibilidade. Entretanto, já está em processo de votação uma Proposta de Emenda à Constituição (PEC 25/12), de autoria do Senador Aloysio Nunes (mesmo autor do PL 288/13 que originou a Lei $\mathrm{n}^{\circ} 13.445 / 17$ ), que permite ao imigrante a possibilidade de exercer direitos políticos em eleições locais. Essa PEC responde a uma demanda antiga das comunidades migrantes, que se estabelecem no país, submetidas às nossas leis e tributos, e não têm a possibilidade de participar do processo político no Brasil, sendo-lhes negado o exercício pleno da cidadania.
} 
"efeitos imprevisíveis sobre a democracia", caracterizando, portanto, uma democracia única no mundo, na qual a ampliação da cidadania conduz justamente a seu temível (adjetivo insubstituível no presente caso) colapso. (grifo nosso)

Outro veto a se destacar foi o imposto ao $\S 4^{\circ}$ do art. 113 da Lei, que previa que seriam considerados vulneráveis e, portanto passíveis de proteção especial, "os solicitantes de refúgio, os requerentes de visto humanitário, as vítimas de tráfico de pessoas, as vítimas de trabalho escravo, os migrantes em cumprimento de pena ou que respondem criminalmente em liberdade e os menores desacompanhados". Como justificativa para o veto, se utilizou o fato de que o dispositivo apresentava "impropriedade, ao arrolar indevidamente como integrante de grupo vulnerável, passível portanto de benefícios no âmbito da política migratória, os indivíduos que respondam criminalmente em liberdade". Ainda que houvesse qualquer dúvida sobre a vulnerabilidade daqueles que, em situação migratória, cumprem sua pena em liberdade; ao excluir essa categoria como motivação principal do veto, ficam também renegadas todas as outras que não parecem figurar dentre as dúvidas de vulnerabilidade do poder executivo, impossibilitando por completo que recebam qualquer tipo de benefício no âmbito da política migratória. Tornar secundarizado o valor humanitário da garantia de maior proteção ao maior número de pessoas desde um prisma de estigmatização da condenação criminal é, no mínimo, menosprezo ao Estado de Direito.

Merece análise, também, o veto ao dispositivo que garantia aos povos indígenas e populações tradicionais ${ }^{22}$ seus direitos originários, em especial o direito à livre circulação em terras tradicionalmente ocupadas ${ }^{23}$ (art. $1^{\circ}, \S 2^{\circ}$ da Lei). Segundo a

\footnotetext{
${ }^{22}$ De acordo com o Decreto $n^{\circ} 6.040 / 2007$, vigente no Brasil, populações tradicionais são: Os grupos culturalmente diferenciados e que se reconhecem como tais, que possuem formas próprias de organização social, que ocupam e usam territórios e recursos naturais como condição para sua reprodução cultural, social, religiosa, ancestral e econômica, utilizando conhecimentos, inovações e práticas gerados e transmitidos pela tradição (art. $3^{\circ}$ ). (grifo nosso).

${ }^{23} \mathrm{~A}$ mobilidade dos povos indígenas e populações tradicionais se divide em quatro modalidades: "A mobilidade internacional propriamente dita trata dos povos indígenas que migram para outros países e não mantém laços com a comunidade de origem. Na mobilidade transnacional, há manutenção dos laços com a comunidade de origem, bem como a criação de novos vínculos no país receptor. A migração internacional forçada trata do deslocamento decorrente de perseguição por parte do Estado, guerras civis ou conflitos internos, ou forma de resistência diante da pobreza no país de origem. Por sua vez, a mobilidade territorial ancestral - que é, ao nosso ver, objeto do $\S 2^{\circ}$ do art. $1^{\circ}$ do Projeto de Lei de Migração - trata dos povos indígenas cujas fronteiras étnicas vão além dos limites dos Estadosnacionais. Nesse sentido, de acordo com a CEPAL, existe um costume jurídico de deslocamento no interior das fronteiras étnico-culturais." DEFENSORIA PÚBLICA DA UNIÂO. Nota Técnica ao SCD $n^{\circ}$ 07 de 2016/ PL no 2.516/2015 / PLS no 288 de 2013, que institui a Lei de Migração. Disponível em: http://www.dpu.def.br/noticias-defensoria-publica-da-uniao/233-slideshow/37322-dpu-divulga-notatecnica-sobre-nova-lei-de-migracao. Acesso em 30 de março de 2018.
} 
presidência da república, o veto se justificaria, pois viola os artigos $1^{\circ}$, l; 20, § 2ํㅜ ; e 231 da $\mathrm{CF} / 88$, que impõem a "defesa do território nacional como elemento de soberania, pela via da atuação das instituições brasileiras nos pontos de fronteira, no controle da entrada e saída de índios e não índios e a competência da União de demarcar as terras tradicionalmente ocupadas, proteger e fazer respeitar os bens dos índios brasileiros".

Ocorre que populações tradicionais e povos indígenas são coletivos que se relacionam com a terra de forma diferente daquela estabelecida pelo homem ocidental (TOMEI; SEWPSTON, 1999, p. 34). Para essas populações, a posse da terra é coletiva e elas não reconhecem fronteiras artificiais traçadas pelo colonizador (SANTILLI, 2000, p. 96). Nesse sentido, a migração está para essas pessoas como um fato e uma necessidade do modo de vida que levam ${ }^{24}$ e a $\mathrm{CF} / 88$, no art. 231 protege não apenas os direitos territoriais, mas também os direitos culturais desses povos.

Resta clara, nas razões do veto, a ideologia de segurança nacional que, após esses vetos, torna a assombrar a tentativa de implementação de um novo modelo de legislação migratória no Brasil. Em detrimento da proteção dos direitos humanos das pessoas migrantes, dos povos indígenas e das populações tradicionais, o veto condena o texto original da Lei à lógica autoritária da legislação anterior, permitindo a primazia do fundamento securitário que se propunha a abandonar quando do início dos debates sobre a necessidade de um novo marco legal.

Por fim, cabe destacar o veto ao art. 118 da nova Lei, que concedia anistia e autorização de residência aos imigrantes que assim o requeressem, desde que tivessem ingressado no território nacional até 6 de julho de 2016, e o fizessem no prazo de 1 (um) ano após a entrada em vigor da Lei, independentemente de sua situação migratória prévia. O veto presidencial foi imposto, pois, na visão da presidência, o artigo concederia "anistia indiscriminada a todos os imigrantes, independentemente de sua situação migratória ou de sua condição pessoal, esvaziando a discricionariedade do Estado para o acolhimento dos estrangeiros". Nesse ponto, o medo anterior de um possível excesso de discricionariedade desaparece e, ao contrário, torna-se o ponto

\footnotetext{
24“O Brasil apresenta diversas comunidades em região de fronteira. Apenas para exemplificar, cita-se os Guarani, nas fronteiras do 'Mercosul', grupo hoje extremamente vulnerável; os Yanomami, na fronteira brasileira/venezuelana, drasticamente reduzidos na época da ditadura militar, em razão da exploração mineral, nuclear e do desflorestamento para construção de estradas na Amazônia" (DAVIS, Shelton H. Vitimas do milagre. O desenvolvimento e os índios do Brasil. Rio de Janeiro: Zahar Editores, 1978, p. 130-133.) "No Acre, há diversos grupos isolados que ocupam a região de fronteira com o Peru." (AQUINO, Terri Valle de. A fronteira dos isolados. In: Revista da sociedade brasileira para o progresso da ciência, ano 65, n. 1, jan./mar. 2013, p. 33). Na tríplice fronteira Brasil, Colômbia e Peru há grande mobilidade indígena e, também, notícias de graves violações a esses povos por empresas mineradoras, garimpeiros, grileiros e madeireiras, entre tantos outros.
} 
central da reivindicação, afinal, como demonstrado na primeira parte desse artigo, para os que adotam um raciocínio comprometido com a ideologia da segurança nacional, escolher quem pode ou não ficar no território faz parte de um conjunto de decisões obscuras e independe de critérios objetivos e de igualdade. Sob essa ótica, Gersztein (2017), aduz que “'anistia' é o instituto jurídico que concede perdão àqueles que cometeram crimes, como, por exemplo, fez a Lei de Anistia com todos que praticaram o terrorismo de Estado no Brasil durante a ditadura civil-militar". Em razão disso, não haveria que se falar em anistia indiscriminada, já que os requisitos para a concessão do benefício foram expressos no texto do dispositivo vetado.

O tom dos vetos já anunciava as distorções que poderiam advir da necessidade de regulamentação por decreto do poder executivo, prevista em vários artigos da Lei de Migração. De fato, em novembro de 2017, o decreto 9199 foi publicado com quase o triplo de artigos do texto legal, sintetizando todo o descaso com as preocupações e tentativas de contribuições da sociedade civil ${ }^{25}$ sobre o tema e reforçando ainda mais a retomada da doutrina de segurança nacional. Apenas a título exemplificativo do conjunto da obra, o texto da regulamentação, no artigo 211 da seção sobre "medidas de retirada compulsória", permite que o delegado da polícia federal possa pedir a prisão de migrantes, contrariando frontalmente o art. 123 da Lei de Migração que afirma que "ninguém será privado de sua liberdade por razões migratórias, exceto nos casos previstos nesta Lei".

As omissões importantes no PL 288/13, que viria a se tornar a Lei no 13.445/17 somadas às imposições de vetos e a regulamentação do decreto presidencial no 9199 , cujas razões se fundamentam exclusivamente na ideologia da segurança nacional, fazem com que a nova Lei de Migração relativize a proteção dos direitos humanos da pessoa migrante e privilegie a discricionariedade dos agentes do Estado dando um considerável passo atrás naquilo que poderia ter sido o maior avanço histórico dessa matéria no Brasil.

\section{CONSIDERAÇÕES FINAIS}

\footnotetext{
${ }^{25} \mathrm{O}$ menosprezo pelas contribuições da sociedade civil, outrora valorizados por algumas instâncias institucionais do Estado brasileiro, está descrito em uma carta de entidades vinculadas ao tema que torna pública não só as contrariedades com o processo de elaboração, mas com o conteúdo final do decreto 9199/17. Disponível em: http://www.missaonspaz.org/single-post/2017/11/18/Carta-abertasobre-o-processo-de-participa\%C3\%A7\%C3\%A3o-social-na-regulamenta\%C3\%A7\%C3\%A3o-da-Lei1345517-e-pontos-preocupantes-na-minuta-do-decreto-da-nova-Lei-de-Migra\%C3\%A7\%C3\%A3o
} 
Lamentavelmente o contexto de aprovação e regulamentação do novo marco legal do tema das migrações no Brasil não foi o mais adequado. Depois de um forte processo de mobilização social com apoio institucional, o desfecho do marco regulatório ocorreu em uma conjuntura pouco favorável ao aprofundamento da democracia brasileira.

Se, por um lado, a atual Lei de Migração aprovada é um passo inestimável na disputa de conceber os migrantes como pessoas portadoras de direitos, os vetos aos quais foi submetida pelo poder executivo com posterior concordância do Congresso Nacional e o resultado final da regulamentação pelo decreto 9.199, não deixam dúvidas de que a democracia não é um valor em si mesma, é um processo de construção constante que avança e retrocede, sem que possamos perder a vigilância, sobretudo, em momentos de retrocesso ao respeito e às garantias de direitos humanos como os que o Brasil passa atualmente.

O espectro autoritário que rondou e ainda rondará a consolidação da nova Lei de Migração deve servir, ao menos, para mostrar o preço político de seu não enfrentamento no momento da repactuação democrática vivido em 1988 e para que nos coloquemos definitivamente em posição não mais só de vigilância, mas de disputa pelas conquistas inequívocas às quais nos levaram os avanços da pauta de direitos humanos no pós-guerra e sem as quais não é possível pensar na retomada da nossa democracia.

\section{REFERÊNCIAS}

ASANO, Camila Lissa; TIMO, Pétalla Brandão. A nova Lei de Migração no Brasil e os direitos humanos. Disponível em: https://br.boell.org/pt-br/2017/04/17/nova-lei-demigracao-no-brasil-e-os-direitos-humanos. Acesso em 12 de março de 2018.

BRASIL. Constituição da República Federativa do Brasil de 1988. Brasília, 1988.

. Conferência Nacional sobre Migrações e Refúgio. Caderno de Propostas.

Disponível em:

http://www.participa.br/articles/public/0007/3665/20141051\%2022_COMIGRAR_Cader no_de_Proposta_Envio.pdf. Acesso em 10 de março de 2018.

. Comissão de Especialistas criada pelo Ministério da Justiça pela Portaria ${ }^{\circ}$ 2.162/2013. Anteprojeto de Lei de Migrações e promoção dos direitos dos migrantes no

Brasil. Brasília, 31 jul. 2015. 
. Diário do Congresso Nacional (DCN), 27 de maio de 1980.

. Diário Oficial da União (DOU), 08 de fevereiro de 2018.

. Lei 6.815 , de 19 de agosto de 1980. Define a situação jurídica do estrangeiro, cria o Conselho Nacional de Imigração. Brasília, 1980.

. Lei 13445, de 24 de maio de 2017. Institui a Lei de Migração. Brasília, 2017.

. Ministério do Trabalho e Emprego. Resolução Normativa no 102, de 26 de abril de 2013. Altera o art. $2^{\circ}$ da Resolução Normativa $n^{\circ}$ 97, de 12 de janeiro de 2012. Disponível em: http://www.acnur.org/t3/fileadmin/Documentos/portugues/Publicacoes/2012/Lei_947_97 _e_Coletanea_de_\%20Instrumentos_de_Protecao_Internacional_de_Refugiados_e_A patridas.pdf?view=1. Acesso 30 nov. 2015.

CLARO, Carolina de Abreu Batista. As Migrações Internacionais no Brasil sob uma Perspectiva Jurídica: análise da legislação brasileira sobre estrangeiros entre os séculos XIX e XXI. Cadernos OBMIGRA. Brasília, v. 1, n. 1, p. 119-210, 2015.

; FAUTH JÚNIOR, Sady Sidney. O processo participativo na elaboração e na consolidação da política migratória brasileira. In: VASCONCELOS, Ana Maria Nogales; BOTEGA, Tuíla (Org.). Política migratória e o paradoxo da globalização. Porto Alegre: Edipucrs, 2015. p. 75-103.

COMBLIN, Joseph. A ideologia da segurança nacional: o poder militar na América Latina. Rio de Janeiro: Civilização Brasileira, 1978.

DIAS, Maria Berenice. As famílias e seus direitos. Disponível em http://www.mariaberenice.com.br/manager/arq/(cod2_568)14_as_familias_e_seus_dir eitos.pdfAcesso em 10 de março de 2018.

FEDERAÇÃO NACIONAL DOS POLICIAIS FEDERAIS. Nota à imprensa: estrangeiros que participarem de atos políticos podem ser detidos e expulsos do país. 16 de abril de 2016. Disponível em: http://fenapef.org.br/nota-a-imprensa-estrangeiros-queparticiparem-de-atos-politicos-podem-ser-detidos-e-expulsos-do-pais/. Acesso em 10 de março de 2018.

GERSZTEIN, Paola Coelho. Quando a discricionariedade vale mais que o direito: análise do elemento comum às razões de veto impostas à Lei de Migração. Revista Mundorama. 17 de agosto de 2017. Disponível em:

https://www.mundorama.net/?p=23862. Acesso em 16 de março de 2018.

GUERRA, Sidney. A Nova Lei de Migrações no Brasil: avanços e melhorias no campo dos direitos humanos. Revista de Direito da Cidade. v. 09, n. 4, pp. 1717-1737.

HONNETH, Axel. Reificación: un estudio en la teoría del reconocimiento. Buenos Aires: Katz, 2007. 
MORAES, Ana Luisa Zago de. Crimigração: a relação entre política migratória e política criminal no Brasil. 2015. 374 f. Tese (Doutorado) - Programa de Pós-graduação em Ciências Criminais, PUCRS, Porto Alegre, 2015.

MINISTÉRIO DAS RELAÇÕES EXTERIORES - MRE (2016): Estimativas populacionais das comunidades brasileiras no Mundo - 2015. Disponível em: http://www.brasileirosnomundo.itamaraty.gov.br/a-comunidade/estimativaspopulacionais-das-comunidades. Acesso em 12 de março de 2018.

MÜLLER, Friedrich. Quem é o povo? A questão fundamental da democracia. São Paulo: Max Limonad, 2003.

NINO, Carlos. Juicio al mal absoluto. Buenos Aires: Ariel, 2006.

OLIVEIRA, Antônio Tadeu Ribeiro de. Nova lei brasileira de migração: avanços, desafios e ameaças. Revista Brasileira de Estudos de População, [s.I.], v. 34, n. 1, pp.171-179, 23 ago. 2017.

, Antônio Tadeu Ribeiro de. Migrações internacionais e política migratória no Brasil. Cadernos OBMIGRA , Brasília, v.1, n.3, 2015.

PEREIRA, Gustavo Oliveira de Lima. Direitos Humanos e Hospitalidade. Porto Alegre. Editora Atlas, 2014. 200p.

PIMENTEL, Marília; COTINGUIBA, Geraldo Castro. Wout, raketè, fwontyè, anpil mizè: reflexões sobre os limites da alteridade em relação à imigração haitiana para o Brasil. Universitas Relações Internacionais, v. 12, n. 1, 2014. p. 75.

REIS, Rossana Rocha. A Política do Brasil para as Migrações Internacionais. Contexto Internacional, Rio de Janeiro, v. 33, n. 1, p. 47-69, jan./jun. 2011.

SANTILLI, Juliana. "Biodiversidade e conhecimentos tradicionais: formas jurídicas de proteção". In: RICARDO, Carlos Alberto (Ed.). Povos Indígenas no Brasil, 1996-2000. São Paulo: Instituto Socioambiental, p. 95-98. 2000.

SECRETARIA NACIONAL DE JUSTIÇA - SNJ. Caderno de Propostas. 1르 Conferência Nacional sobre Migrações e Refúgio. Brasília: SNJ, maio 2014a.

. Caderno de Propostas Pós-Etapa Nacional. $1^{\text {a }}$ Conferência Nacional sobre Migrações e Refúgio. Brasília: SNJ, jun. 2014b.

. Manual Metodológico. 1르 Conferência Nacional sobre Migrações e Refúgio. Brasília: SNJ, jan. 2014c.

Regimento Interno da $1^{a}$ Conferência Nacional sobre Migrações e Refúgio (COMIGRA). Disponível em: http://www.participa.br/articles/pu\%20blic/0007/4446/Regimento_interno_COMIGRAR_2014_etapa_nacional_\%20final_ 1_.pdf

Acesso em: 13 fev. 2015.

Texto Base COMIGRAR. $1^{\text {a }}$ Conferência Nacional sobre Migrações e Refúgio. Brasília: SNJ, jan. 2014d. 
SENADO FEDERAL. Regimento Interno: resolução no 93, de 1970. Brasília: Senado Federal, 2011.

TOMEI, Manuela; SEWPSTON, Lee. Povos indígenas e tribais: guia para a aplicação da Convenção n. 169 da OIT. Brasília: OIT, 1999. p. 34.

UNIVERSIDADE FEDERAL DE MINAS GERAIS. Justiça Federal manda arquivar inquérito contra professora italiana da UFMG. 3 de junho de 2016. Disponível em: https://www.ufmg.br/online/arquivos/043795.shtml. Acesso em 13 de março de 2018.

VENTURA, Deisy; ILLES, Paulo. Qual a política migratória do Brasil. In: Le Monde Diplomatique Brasil, 07 mar 2012. Disponível em:

https://diplomatique.org.br/artigo.php?id=1121 . Consulta em 10 mai 2014.

Recebido em 30/04/2018

Aprovado em 06/09/2018

Received in 30/04/2018

Approved in 06/09/2018 